\title{
KEDUDUKAN BADAN HUKUM SEBAGAI SUBJEK HUKUM DALAM HUKUM EKONOMI SYARIAH
}

\author{
Panji Adam Agus Putra \\ Fakultas Syariah Universitas Islam Bandung \\ DOI : https://doi.org/10.29313/shjih.v17i2.5923
}

\begin{abstract}
ABSTRAK
Dalam studi hukum ekonomi Islam, pembahasan kontrak menempati posisi yang sangat penting. Kontrak dikatakan valid ketika kepatuhan terhadap syarat dan ketentuan untuk validitas perjanjian syariah. Salah satu hal yang harus dipenuhi adalah pihak-pihak yang melaksanakan kontrak. Dalam kajian fiamih muamalah klasik, pihak-pihak yang menjadi subjek hukum hanya bersifat individual, tetapi masa saat ini telah berkembang, tidak hanya individu, tetapi juga entitas hukum yang tunduk pada hukum. Posisi subjek hukum ini diakui dalam perspektif hukum ekonomi syariah karena merupakan hasil analogi eksistensi manusia sebagai subjek hukum selama tidak bertentangan dengan prinsip-prinsip syariah. Dalam hal fiqh muamalah, badan hukum biasanya disebut syakhsyiyyah i'tibariyah. Implementasi dalam konteks hukum ekonomi Islam adalah dalam bentuk perjanjian kemitraan kontemporer.
\end{abstract}

Kata kunci: Badan Hukum, Subjek Hukum, Hukum Ekonomi Syariah

\begin{abstract}
In the study of Islamic economic law the discussion of the contract occupies a very important position. The contract is said to be valid when compliance with the terms and conditions for the validity of the sharia agreement. One of the about that must be fulfilled is the parties who carry out the contract. In the classical muamalah fiqh study the parties that are the subject of law are only individal, but times agothere is a development, not only individuals who are legal subjects, but also legal entities are subject to law. The position of this legal subject is recognized in the perspective of sharia economic law because it is the result of an analogy of human existence as a legal subject as long as it does not contradict sharia principles. In terms of fiqh muamalah the legal entity is usually called syakhsyiyyah i'tibariyah. The implementation in the context of Islamic economic law is in the form of contemporary partnership agreements.
\end{abstract}

Keywords: Legal Entity, Legal Subjects, Sharia Economic Law 


\section{A. PENDAHULUAN}

Ekonomi dan keuangan Islam bukanlah hal yang baru, namun telah ada sejak mumculnya Islam itu sendiri, yang merupakan bagian integral Islam sebagai panduan hidup, sehingga filosofi dasar ekonomi dan keuangan Islam tidak terlepas dari filosofi untuk mencapai kebahagiaan dan kesejahteraan hakiki di dunia dan akhirat. ${ }^{1}$ Menurut Ma'ruf Amin, ${ }^{2}$ ekonomi syariah ${ }^{3}$ adalah ekonomi yang didasarkan pada wahyu Ilahi yang diturunkan untuk kemaslahatan dan kesejahteraan umat manusia. Sistem ekonomi syariah berakar kuat pada norma dan etika Islami yang bersumber dari ketentuan Al-Quran dan sunnah. Tujuan utama penerapan sistem ekonomi syariah adalah merealisasikan masyarakat yang adil dan sejahtera. Dalam pandangan Islam, kesejahteraan dinamika secara konprehensif, yakni realisasi kehidupan meterial dan spiritual secara seimbang. Konsep keseimbangan ini bahkan sudah inheren dalam kata iqtishâd itu sendiri, yang berarti

\footnotetext{
${ }^{1}$ Darsono, dkk, Perbankan Syarah Di Indonesia: Kelembagaan Dan Kebijakan Serta Tantangan Ke Depan, PT RajaGrafindo Persada, Jakarta, 2017, hlm. 31.

2 Ma'ruf Amin dalam Hasbi Hasan, Pemikiran Dan Perkembangan Hukum Ekonomi Syariah Di Dunia Islam Kontemporer, Gramata Publishing, Depok, 2011, hlm. vii.

${ }^{3}$ Istilah "ekonomi syariah" merupakan sebutan yang khas digunakan di Indonesia. Di luar Indonesia, istilah ini lebih populer dengan sebutan "ekonomi Islam" (al-iqtishâd al-islâmî, islamic economic). Dalam wacana pemikiran ekonomi Islam kontemporer, konsep ekonomi islam memang sering diidentifikasi dengan pelbagai istilah yang berbeda, antara lain "ekonomi Islam", "ekonomi ilahiyyah", "ekonomi Qur'ani”, “ekonomi syariah", "ekonomi berdasarkan prinsip bagi hasil" dan "ekonomi rahmatan lil "alamin". Semua istilah ini mengacu kepada suatu konsep sistem ekonomi dan kegiatan usaha berdasarkan hukum Islam atau ekonomi bedasarkan prinsip syariah". Perbedaan penggunaan istilah ini pada dasarnya menunjukan bahwa istilah "ekonomi Islam" bukanlah nama baku dalam terminologi Islam. Lihat, ibid, hlm. 19.
} 
moderat atau seimbang (al-tawâsut wa al-i'tidâl). Tujuan mulia inilah yang membuat ekonomi syariah memiliki karakter universal.

Fikih muamalah menduduki posisi yang sangat penting dalam ekonomi hukum syariah, karena ia mengatur perilaku kehidupan ekonomi dan keuangan, baik individu, lembaga maupun negara. Namun harus dicatat, bahwa pemikiran (ijtihad) ulama yang tertuang dalam kitab-kitab fikih muamalah bukanlah hukum Tuhan yang bersifat absolute. ${ }^{4}$ Salah satu perubahan dalam sistem transaksi ekonomi syariah, yakni munculnya perkembangan kategori subjek hukum yang awalnya hanya manusia (persoon) bertambah menjadi badan hukum. Dalam kajian fikih muamalah klasik tidak ditemukan adanya subjek hukum dalam bentuk badan hukum, akan tetapi seiring dengan perkembangan zaman subjek hukum dalam bentuk badan hukum ini terimplementasikan dalam berbagai kegiatan transaksi ekonomi.

Berbicara mengenai subjek hukum tidak akan terlepas dari konsep akad dalam fikih muamalah. Mayoritas ulama berpendapat bahwa rukun akad terdiri dari 3 komponen, yaitu ijab, kabul dan objek ,. Oleh karena itu, perlu dilakukan adanya penelitian mengenai kedudukan badan hukum sebagai subjek hukum yang dalam literatur fikih klasik subjek hukum hanya dikenal dalam bentuk manusia (persoon). Hal ini berimplikasi terhadap sah atau tidak sahnya transaksi yang dilakukan oleh badan hukum. Oleh karena itu, tujuan penelitian ini adalah untuk pertama, mengetahui serta menganalisis kedudukan badan hukum sebagai subjek hukum perspektif hukum ekonomi syariah; kedua, untuk mengetahui implementasi badan hukum sebagai subjek hukum dalam hukum ekonomi syariah.

\section{B. PEMBAHASAN}

\section{A. Kedudukan Badan Hukum Sebagai Subjek Hukum dalam Hukum Ekonomi Syariah}

\section{Subjek Hukum dalam Perspektif Hukum Ekonomi Syariah}

\footnotetext{
${ }^{4}$ Agustianto, Reaktualisasi dan Kontekstualisasi Fikih Muamalah Ke-Indonesiaan: Upaya Inovasi Produk Perbankan dan Keuangan Syariah, Iqtishad Publishing, Ciputat, 2014, hlm. 14.
} 
Berbicara mengenai subjek hukum dalam perspektif fikih muamalah (baca: hukum ekonomi syariah) tidak terlepas dari konsep akad ${ }^{5}$ atau perjanjian dalam hukum Islam. Dalam hukum Islam untuk terbentukmya suatu akad (perjanjian) yang sah dan mengikat haruslah dipenuhi (1) rukun akad dan (2) syarat akad. Rukun adalah unsur-unsur yang membentuk sesuatu, sehingga sesuatu itu terwujud karena adanya unsur-unsur tersebut yang membentuknya. Dalam konsepsi hukum Islam, unsur-unsur yang membentk sesuatu itu disebut rukun. ${ }^{6}$

Akad yang terbentuk karena adanya unsur-unsur atau rukun-rukun yang membentuknya. Menurut mayoritas ahli hukum Islam, rukun yang membentuk akad ada 3 unsur sebagai berikut: (1) shighat (صيغة) pernyataan ijab kabul; (2) 'Aqidain (عاقدين) para pihak yang melakukan akad; (3) Ma'qud 'Alaih (معقود عليه) objek akad. Sementara itu, menurut mazhab Hanafi, rukun akad hanya terdiri atas ijab dan kabul (shighat). Selain itu, ulama mazhab Hanafi menambahkan satu hal lagi dalam rukun akad, yaitu maudhu' al- 'aqd (tujuan akad). ${ }^{7}$ Sedangkan hal lain yang oleh jumhur/mayoritas dipandang sebagai rukun akad, bagi mazahab Hanafi dipandang sebagai lawâzim al-'aqd (hal-hal yang mesti ada dalam setiap pembentukan kontrak) dan terkadang disebut dengan muqâwimat al-'aqd (pilar-

${ }^{5}$ Pasal 1 angka (13) Undang-Undang Nomor 21 Tahun 2008 tentang Perbankan Syariah memberikan pengertian mengenai akad, yaitu kesepakatan tertulis antara Bank Syariah atau UUS dan pihak lain yang memuat adanya hak dan kewajiban bagi masing-masing pihak sesuai dengan Prinsip Syariah. Batasan akad lebih luas terdapat dalam Pasal 10 ayat (1) Kompilasi Hukum Ekonomi Syariah (KHES), yang dimaksud dengan akad adalah kesepakatan dalam suatu perjanjian antara dua pihak atau lebih untuk melakukan dan atau tidak melakukan perbuatan hukum tertentu.

${ }^{6}$ Syamsul Anwar, Hukum Perjanjian Syariah: Studi tentang Teori Akad dalam Fikih Muamalat, Jakarta, RajaGrafndo Persada, 2007, hlm. 95.

${ }^{7}$ Izzudin Muhammad Khujah, Nadzariyat al- 'Aqd fî al-Fiqh al-Islâmî, Jeddah, Dallah alBarakah, 1993, hlm. 23. Lihat juga Musthafa Ahmad Zarqa, al-Madkhal al-Fiqh al-'Âm: Fiqh alIslâm fî Tsaubih al-Jadîd, Beirût, Dâr al-Fikr, 1986, Juz. I, hlm. 288-290. 
pilar akad). Dengan demikian, secara garis besar, rukun-rukun akad itu ada 4 (empat) komponen, yakni sîghat al- 'aqd (pernyataan ijab kabul), al-âqidâin (pelaku akad), al-ma'qûd 'alaih (objek akad), al-maudhu al-'aqd (akibat hukum/tujuan akad). ${ }^{8}$

Berbicara mengenai subjek hukum, berarti berbicara pula mengenai alâqidâin (pelaku akad). Ijab dan kabul yang merupakan komponen atau rukun akad tidak mungkin terwujd tanpa adanya pihak-pihak yang melakukan akad. Oleh karena itu, pihak-pihak yang melakukan akad merupakan faktor utama pembentuk suatu perjanjian. Cakupan subjek akad ini, dalam fikih pada awalnya lebih menunjukan kepada perseorangan dan tidak dalam bentuk badan hukum. ${ }^{9}$ Menurut fikih, dalam subjek hukum akad perorangan, tidak semua orang dipandang cakap mengadakan akad. Ada yang sama sekali dipandang tidak cakap, ada yang dipandang cakap mengenai sebagian tindakan dan tidak cakap sebagaian lainnya, dan ada pula yang dipandang cakap melalukan segala macam tindakan.

Berkaitan dengan kecakapan orang yang melakukan akad ini, para fukaha (ahli hukum Islam) membahasnya pada 2 (dua) hal pokok, pertama, ahliyah (kecakapan hukum). Ahliyah ini terbagi kepada dua macam lagi, yaitu ahliyyatul wujûb dan ahliyyatul ada'. Ahliyyatul wujûb adalah kecakapan menerima hukum (kecakapan hukum secara pasitf), sedangkan ahliyyatul ada' adalah kecakapan bertindak hukum (kecakapan hukum aktif). Masing-masing dari dua kecakapan tersebut dibedakan menjadi kecakapan tidak sempurna dan kecakapan sempurna, sehingga ada 4 (empat) tingkatan kecakapan hukum, yaitu sebagai berikut: (1) ahliyyatul wujûb an-naqishah, yang dimiliki subjek hukum berada dalam kandungan ibu; (2) ahliyyatul wujûb al-kamilah, yang dimiliki oleh subjek hukum sejak lahir hingga meninggal (menjelang dewasa); (3) ahliyyatul ada' an-naqishah, yang dimiliki subjek hukum ketika berada dalam usia tamyiz dan (4) ahliyyatul ada'

\footnotetext{
${ }^{8}$ Hendi Suhendi, Fiqh Muamalah, Jakarta, PT RajaGrafindo Persada, 2005, hlm. 47-48.

${ }^{9}$ Uraian mengenai kedudukan badan hukum sebagai subjek hukum diurai setelah pembasan mengenai subjek hukum dalam perspektif hukum ekonomi syariah.
} 
al-kamilah, yang dimiliki subjek hukum sehak menginjak dewasa hingga meninggal. ${ }^{10}$

Macam ahliyyah tersebut, maka yang sesuai dengan konteks pembicaraan kelayakan melakukan akad ini adalah ahliyyatul ada'. Ahliyyatu; 'ada, yaitu kelayakan seseorang untuk memenuhi kewajiban yang ditetapkan syara atay orang yang layak dengan sendirinya dapat melakukan berbagai akad, di mana seseorang tersebut layak mendapat ketetapan untuk menerima hak dan kewajiban, serta tindakan-tindakan sesuai dengan perjanjian yang dibuatnya yang dibenarkan syara'. Di samping juga terbebas dari kemungkinan terhalangnya kelayakan tersebut ('awâridhul ahlyyah). ${ }^{11}$ Penentuan kelayakan ini, para fukaha (ahli hukum Islam)

${ }^{10}$ Fathurrahman Djamil, Penerapan Hukum Perjanjian dalam Transaksi di Lembaga Keuangan Syariah, Jakarta, Sinar Grafika, 2012, hlm. 32.

${ }^{11}$ Menurut para ahli, kondisi yang memengaruhi kompetensi terbagi menjadi 2 (dua), yaitu pertama, kondisi yang memengaruhi akal. Faktor-faktor yang memengaruhi akal sehingga pelaku akad tidak bisa berpikir, di antaranya adalah gila, tidur, pingsan, dan mabuk. Apabila kondisi-kondisi tersebut menimpa pelaku akad, maka akadnya tidak sah dan tidak melahirkan hak dan kewajiban. Hukumnya sama dengan hukum akad yang dilakukan oleh anak kecil (yang belum mumayyiz), yang bertanggung jawab terhadap setiap konsekuensi hukum akad tersebut adalah walinya. Kedua, kondisi yang tidak memengaruhi akal. Faktor-faktor yang tidak memengaruhi akal, tetapi pelaku tidak bisa berpikir, seperti kondidsi lupa, orang yang tidak menggunakan harta, berutang dan sakaratul maut. Jika kondisi-kondisi tersebut menimpa pelaku akad, maka pelaku tersebut dilarang melakukan transaksi. Lihat, Oni Sahroni dan M. Hasanuddin, Fikih Muamalah: 
sering menyebutkan dengan istilah mukallaf, yaitu akil baligh, berakal sehat, dan cakap hukum. Adapun batasan umur mukallaf tersebut biasanya diserahkan kepada tradisi di masyarakat ( 'urf) atau perarturan perundang-undangan. ${ }^{12}$

Al-wilayah (perwalian). Kata al-wilayah ini berarti adanya kewenangan atau kekuasaan yang diberikan oleh syara' atau undang-undang kepada seseorang untuk melakukan tindakan suatu akad, yang mempunyai akibat-akibat hukum. Kewenangan perwalian ini terdapat dalam beberapa bentuk, ada yang disebut niyabah ashliyyah, yaitu seseorang yang mempunyai kecakapan sempurna dan melakukan tindakan hukum untuk kepentingan dirinya sendiri. Ada juga yang disebut dengan niyabah al-syar'iyyah atau wilayah niyabiyah, yaitu kewenangan atau kekuasaan yang diberikan kepada pihak lain yang mempunyai kecakapan sempurna untuk melakukan tindakan hukum atas nama orang lain. Bentuk kedua ini, baik karena ikhtiyariyah (memilih menentukan sendiri) atau berdasarkan ijbariyah (keputusan tetap hakim untuk menunjuk seseorang melakukan perwalian terhadap pihak-pihak yang mengharuskan adnaya perwalian, atau pihak lain sebaga wakil atas namanya berdasarkan ketetapan/keputusan hakim). ${ }^{13}$

Perbedaan antara ahliyatul ada' dan al-wilayah antara lain ahliyyatul ada' adalah kepantasan seseorang untuk berhubungan dengan akad, sedangkan alwilayah adalah kepantasan seseorang untuk melaksanakan akad. Mislanya, seseorang dinilai dapat berhubungan dengan akad apabila orang tersebut telah dewasa, sedangkan yang belum dewasa (anak-anak), aia dapat melaksanakan akad, namun kepada hal-hal yang terbatas sesuai kebiasaan ('urf) atau akad tersebut diwakilkan kepada walinya atas nama anak-anak tersebut. ${ }^{14}$

Dinamika Teori Akad dan Implementasinya dalam Ekonomi Syariah, Jakarta, RajaGrafindo Persada, 2016, hlm. 35-36.

${ }^{12}$ Untuk kasus di Indonesia, kecakapan (ahliyyah) para pihak ini apabila telah berumur 18 tahun, sudah menikah walaupun belum berumur 18 tahun, tidak dibawah pengampuan atau pailit.

${ }^{13}$ Fathurrahman Djamil, Loc. Cit., hlm. 33.

${ }^{14}$ Ibid., hlm. 33. 


\section{Kedudukan Badan Hukum sebagai Subjek Hukum dalam Hukum} Ekonomi Syariah

Pada awalnya, dalam kajian fikih muamalah/hukum ekonomi syariah, yang termasuk subjek hukum adalah manusia perseorangan dan tidak badan hukum. Namun sesuai dengan perkembangannya, subjek akad ini tidak saja berupa orang perseorangan (al-ahwâl al-syakhsiyyah/natuurlijk persoon), tetapi berbentuk badan hukum (al-syakhsyiyyah al-itibariyyah atau al-syakshiyyah alhukmiyyah/rechpersoon). ${ }^{15}$

Pihak-pihak yang terlibat dalam akad dapat terdiri dari manusia dan badan hukum. Manusia sebagai pendukung hak dan kewajiban, diawali sejak ia lahir dan berakhir sampai yang bersangkutan meninggal dunia. Bahkan dapat dianggap sebagai pembawa hak atau dianggap telah lahir jika kepentingannya menghendaku, (misalnya dalam hal pembagian kewarisan). Adapun subjek hukum yang berupa badan hukum (al-syakhshiyyah al-hukmiyyah/i'tibariyyah), kapatisanya sebagai pendukung hak dan kewajiban dipersamakan dengan manusia atau dalam istilah fikih disebut dengan al-syakhshiyyah al-thabi'iyah. ${ }^{16}$

Istilah badan hukum (syakhsiyyah i'tibariyah) tidak disebutkan secara khusus dalam pandangan fikih. Badan hukum dikatakan sebagai subjek hukum karena terdiri dari kumpulan orang-orang yang melakukan perbuatan hukum (tasharruf). ${ }^{17}$ Badan hukum merupakan hasil analogi dari keberadaan manusia

\footnotetext{
${ }^{15}$ Dalam ketentuan yang ada, badan hukum biasanya diartikan adalah"...segala sesuatu yang berdasarkan tuntutan kebutuhan masyarakat yang oleh hukum diakui sebagai pendukung hak dan kewajiban" atau "segala sesuatu yang menurut hukum dapat mempunyai hak dan kewajiban". Lihat, Chaidir Ali, Badan Hukum, Bandung, Alumni, 1991, hlm. 81.

${ }^{16}$ Imron Rosyadi, Akad Nominaat Syariah: Implementasi dan Penyelesaian Sengketa, Jakarta, Kencana Prenada Media Group, 2019, hlm. 12.

17 Tasharruf adalah setiap perbuatan (yang dilakukan oleh seseorang atas dasar kehendaknya) yang berimpleikasi lahirnya hak dan kewajiban dengan landasan syara'. Menurut para ahli hukum Islam, tasharruf terbagi menjadi 2 (dua) macam, pertama, tasharruf qauli (ucapan), yaitu ucapan yang bersumber dari satu pihak yang melahirkan hak dan kewajiban, seperti al-bai' (jual beli), ijârah (sewa-menyewa/upah-mengupah) dsb. Kedua, tasharruf fi'li (perbuatan), yaitu perbuatan yang dilakukan secara sadar yang melahirkan akibat hukum, seperti serah terima jual beli, memanfaatkan hal-hal mubâh dsb. Lebih lanjut para pakar membagi jenis tasharruf qauli (ucapan) terbagi menjadi 2 (dua) bagian, yaitu (1) tasharruf yang berbentuk akad (tasharruf qauli aqdi), yitu setiap ucapan yang timbul dari kesepakatan antara dua belah pihak atau lebih, seperti kesepakatan
} 
sebagai subjek hukum. Ketentuan menjadikan badan hukum sebagai subjek hukum, tidak boleh bertentangan dengan prinsip-prinsip akad yang terdapat dalam al-Quran dan Sunnah. keberadaan badan hukum terkait dengan adanya penerapan akad wakalah dalam pembagian tugas (job description) dari suatu manajemen perusahaan. Dalam hal ini manusia bertindak sebagai wakil dari organ lembaga atau perusaan tersebut. Meskipun atas nama badan hukum seseorang menjalankan amanah perusahaan, namun sebagai pertanggungjawaban vertikal tetap dikembalikan kepada amalan individu masing-masing sesuai dengan al-Quran surah al-Muddatsir (74) ayat 38. ${ }^{18}$

Selain melalui metode analogi sebagaimana dijelaskan di atas, menurut hemat penulis kedudukan badan hukum sebagai subjek hukum dapat disetarakan dengan orang (person) karena keduanya memangku hak dan kewajiban ( $\underline{\text { uqu}} \mathbf{u}$ wal iltizâmât). Selain keduanya mengembang hak-hak dan kewajiban, badan hukum pun sama seperti orang perorangan, dapat dituntut dimuka pengadilan. Oleh karena itu, sama halnya dengan orang perorangan badan hukum pun memiliki kedudukan sebagai subjek hukum.

Khalid Ibn Abdullah al-Aziz Ibn Ibrahim al-Juraid, dalam risalahnya yang berujudl al-Syakhsiyyah al-I'tibâriyah memberikan definisi mengenai badan hukum atau syakhsiyyah i'tibariyah sebagai berikut:

dalam akad-akad jual beli, sewa-menyewa, wakaf, wasiat dsb; (2) tasharruf selain akad (tasharruf qauli ghair aqdi) adalah keinginan pihak akad untuk melangsungkan atau membatalkan akad (ucapan sepihak), seperti $d a$ 'wa (tuntutan), dan iqrar (pengakuan), wakaf, talak, ibra' (pelepaskan hak piutang) dsb. Kemudian untuk jenis tasharruf qauli aqdi ini, para pakar membagi ke dalam dua bagian, yaitu (a) ucapan yang berisi keinginan sepihak untuk mendapatkan hak atau membatalkannya (menggugurkannya), seperti wakaf, ju'alah (saembara), ibra' dan wasiat; (b) ucapan yang berisi informasi, seperti da'wa dan iqrar. Lihat, Izzuddin Muhammad Khujah, Nazhariyat al-'Aqd fí al-Fiqh al-Islâmî, Jeddah, Dallah al-Barka, 1993, hlm. 12.

${ }^{18}$ Burhanuddin S, Hukum Bisnis Syariah, Yogyakarta, UII Press, 2011, hlm. 7-8. 


$$
\begin{aligned}
& \text { الشخص الاعتبارى هو مجموعة من الاشخاص او الاموال ترمى الى تحقيق غرض معين } \\
& \text { وتمنح الشخصية القانونية بالقدر الالزم لتحقيق هذا الغرض } 19
\end{aligned}
$$

"Badan hukum adalah sekumpulan orang atau dana yang dimaksudkan untuk mencapai tujuan tertentu dan diberikan kepribadian hukum sejauh yang diperlukan untuk mencapai tujuan itu”.

$$
\text { مستقلا عنها يتكون اجتماع عناصر اشخاص او اموال يقدره التشريع كيانا قانونة منتزعا منها }
$$

"Seseorang yang terdiri dari perkumpulan orang atau dana yang diperkirakan oleh undang-undang sebagai badan hukum yang diambil darinya"

$$
\text { هو اجتمعت لتحقيق الشخص الاعتبارى عبارة عن جماعات من الاشخاص او بجموعات من الاموال }
$$

"badan hukum adalah sekumpulan orang atau dana yang telah bertem untuk mencapai tujuan tertenu, mereka memilik entitas mandri dan hak keuangan yang bersifat independen dan tidak terikat dengan kehidupan atau kematian orang yang membentuknya”.

Berdasarkan definisi yang dipaparkan oleh para pakar di atas, kemudian dapat dirumuskan unsur-unsur dari badan hukum sebagai berikut:22 pertama, sekumpulan orang atau harta yang diselenggarakan dengan kehidupan yang bebas dari orang-orang yang membentuknya untuk memastikan kemajuan pekerjaan untuk mencapai tujuan kebaikan, manfaat umum dan profit semata; kedua, tujuan yang ingin dicapai haruslah melalui badan hukum, baik itu kumpulan orang atau t.th, hlm. 67 .

${ }^{19}$ Khalid Ibn Abdullah al-Aziz Ibn Ibrahim al-Juraid, al-Syakhsiyyah al-I’tibâriyah, t.t, t.p,

\footnotetext{
${ }^{20}$ Ibid.

${ }^{21}$ Ibid.

${ }^{22}$ Ibid., hlm. 71-73.
} 
harta, karena jika tidak ada tujuan atau proyek tidak dapat dibentuk badan hukum; ketiga, selain letimigasi tujuan yang hendak capai, akan tetapi itu tidak cukup, tetapi mensyaratkan bahwa tujuan tersebut dicirikan oleh adanya kontinuitas periode tertentu yang cukup, bahkan jika badan hukum didirikan dalam periode waktu yang cukup lama; keempat, wajib adanya perkongsian untuk merealisasikan tujuan baik berupa perkumpulan orang atau harta karena tidak akan teralisasi badan hukum ini apabila dilakukan hanya secara perorangan, karena tujuan dari dibentuknya badan hukum adalah untuk tujuan bersama.

Menurut Hasbi Assidieqy, ${ }^{23}$ ada perbedaan mendasar antara subjek hukum manusia dan badan hukum. Pertama, badan hukum sebagai pendukung hak bersifat terbatas tidak seperti manusia yang mempunyai hak berkeluarga, pertalian nasab, waris dan sebagainya. Kedua, beakhirnya badan hukum terjadi melalui kesepakatan para pengurusnya atau melalui putusan pengadilan, sedangkan subjek hukum manusia berakhir dengan kematian manusia itu sendiri. Ketiga, badan hukum membutuhkan pengakuan secara hukum yang ketentuannya diatur oleh peraturan perundang-undangan, sedangkan manusia tidak membuthkan pengakuan secara hukum. Kempat, badan hukum bagi segala rupa tasharufnya, mencari hasil, berusaha dan sebagainya, tidak terbatas. Hanya menjadi kurang atau hilang apabila hal-hal yang datang kemudian. Kelima, badan hukum berkembang menurut perkembangan manusia sendiri, dimulai dari ahliyah naqishah berakhir pada ahliyah kamilah, yaitu apabila seseorang telah dewasa. Berbeda dengan manusia, ahliyah-nya telah sempurna dengan berujudnya syakhsiyah ini dan tetap tidak berkembang. Keenam, badan hukum tidak dapat dijatuhi hukuman badan, yang dijatuhi hanya hukuman perdata saja.

Dalam konteks hukum di Indonesia, kedudukan badan hukum sebagai subjek hukum terdapat dalam Pasal 1 angka (1) Kompilasi Hukum Ekonomi Syariah yang berbunyi: "Subjek hukum adalah orang perorangan, persekutuan, atau badan usaha yang berbadan hukum atau tidak berbadan hukum yang memiliki

${ }^{23}$ Teungku Muhammad Hasbi Ash-Shiddieqy, Pengantar Fiqh Muamalah, Semarang, PT Pustaka Rizki Putra, 2001, hlm. 204-205. 
kecakapan hukum untuk mendukung hak dan kewajiban”. Berkaitan dengan kecapakan hukum dalam badan usaha, Pasal 2 angka (1) Kompilasi Hukum Ekonomi Syariah menjelaskan sebagai berikut: "Badan usaha yang berbadan hukm atau tidak berbadan hukum, dapat melakukan pebuatan hukum dalam hal tidak dinyatakan faflis/pailit berdasarkan putusan pengadilan yang telah memperoleh kekuatan hukum tetap".

Berkaitan dengan hal perwalian dalam badan hukum, Pasal 5 ayat (2) Kompilasi Hukum Ekonomi Syariah menjelaskan: "Dalam hal badan hukum terbukti tidak mampu lagi berprestasi sehingga menghadapi kepailitian, atau tidak mampu membayar utang dan meminta permohonan penundaan kewajiban pembayaran utang, maka pengadilan dapat menetapkan kurator atau pengurus bagi badan hukum tersebut atas permohonan pihak yang berkepentingan.

\section{B. Implementasi Badan Hukum Sebagai Subjek Hukum dalam Hukum Ekonomi Syariah}

\section{Syirkah At-Tadhâmun}

Berkaitan dengan implementasi badan hukum dalam konteks hukum ekonomi syariah, maka tidak dapat dilepaskan dengan konsep perkongsian atau biasa disebut dengan istilah akad syirkah atau musyârakah. ${ }^{24}$

24 Dalam literatur ilmu fikih terdapat tiga istilah yang mengacu kepada pengertian percampuran, kemitraan, persekutuan, dan perkongsian, yaitu al-musyarakat, al-syirkat, dan alsyarikat. Yang lebih tepat dari ketiga istilah itu adalah al-syirkat, oleh karena itu, literatur ilmu fikih lebih banyak mempergunakan istilah ini sedangkan peraturan perbankan syariah mempergunakan istilah musyarakah. Secara bahasa al-syirkat berarti al-ikhtilat (campur). Diartikan demikian karena seseorang mencampurkan hartanya dengan harta orang lain sehingga tidak bisa dibedakan dan dipisahkan antara yang satu dengan yang lain. Makna ini menunjukan bahwa dua orang atau lebih mengumpulkan modal guna membiayai suatu investasi. Di sini, bank yang memberikan fasilitas musyarakah kepada nasabah ikut berpartisipasi (take a part) dalam suatu proyek yang baru atau dalam suatu perusahaan yang telah berdiri dengan cara membeli saham dari perusahaan tersebut. 
Definisi al-syirkat menurut para ulama aliran fikih ini diakomodir oleh fatwa DSN-MUI. Fatwa, dalam kaitannya dengan pembiayaan, mengartikan alsyirkat dengan, "Pembiayaan berdasarkan akad kerjasama antara dua pihak atau lebih untuk suatu usaha tertentu yang masing-masing pihak memberikan kontribusi dana dengan ketentuan bahwa keuntungan dan risiko akan ditanggung bersama sesuai kesepakatan". Pengertian ini dijadikan landasan oleh UU No. 21 Tahun 2008 tentang Perbankan Syariah dalam mendefinisikan al-syirkat secara operasional.

Syirkah merupakan akad yang diperbolehkan, hal ini berlandaskan atas dalil-dalil yang terdapat dalam Al-Qur'an, hadits ataupun ijma para ulama. Keabsahan transaksi berdasarkan kongsi atau akad syirkah ini selain berdasarkan sumber hukum Islam, dalam konteks di Indonesia akad syirkah diatur dalam peraturan perundang-undangan, salah satunya adalah UU No. 21 Tahun 2008 tentang Perbankan Syariah.

Undang-Undang menyebutkan akad musyarakah di lima tempat, yaitu pada Pasal 1 ayat (25) huruf a tentang pembiyaan berupa transaksi bagi hasil, Pasal 19 ayat (1) huruf c tentang kegiatan usaha Bank Umum Syariah berupa penyaluran pembiyaan, Pasal 19 ayat (2) huruf c tentang kegiatan usaha UUS berupa penyaluran pembiyaan, Pasal 19 ayat (1) dan (2) masing-masing huruf I tentang kegiatan usaha Bank Umum Syariah dan UUS berupa pembelian, penjualan atau menjamin atas risiko sendiri surat berharga pihak ketiga yang diterbitkan atas dasar transaksi nyata berdasarkan prinsip syariah, dan Pasal 21 huruf b angka 1 tentang kegiatan usaha BPRS berupa penyaluran pembiyaan bagi hasil.

Syirkah terbagi menjadi dua macam, yaitu syirkah amlak (kongsi harta) dan syirkah 'uqud (kongsi transaksi). Dalam hukum positif, syirkah amlak dianggap sebagai syirkah paksa (ijabiriyah), sedangkan syirkah 'uqud dianggap sebagai syirkah sukarela (ikhtiyariyah). Kemudian para fukaha (ahli hukum Islam) memberikan rincian mengenai akad musyarakah ini memiliki beberapa rukun yang telah digariskan oleh ulama guna menentukan sahnya akad tersebut, rukun yang

Lihat, Atang Abd Hakim, Fiqih Perbankan Syariah: Transformasi Fiqih Muamalah Ke dalam Peraturan Perundang-Undangan, Bandung, Refika Aditama, 2011, hlm. 244-245 
dimaksud adalah shîgat (iijab dan kabul), pihak yang bertransaksi (subjek hukum), dan objek transaksi (modal dan kerja).

Berkaitan dengan implementasi badan hukum sebagai subjek hukum dalam konteks hukum ekonomi syariah, para ulama fikih kontemporer berpendapat bahwa badan hukum terimplementasikan pada akad-akad syirkah/musyârakah kontemporer (mu'âshirah). Wahbah al-Zuhailii ${ }^{25}$ dalam kitab-nya Fiqh al-Islâmî wa Adillatuh memperkenalkan akad-akad kongsi (musyârakah) kontemporer, yang dalam analisis penulis akad-akad musyârakah kontemporer ini sebagai bentuk implementasi eksistensi badan hukum sebagai subjek hukum perspektif hukum ekonomi syariah. Adapun yang termasuk kedalam akad-akad musyârakah kontemporer adalah sebagai berikut:

\section{Syirkah At-Tadhâmun}

Menurut Wahbah al-Zuhaili, yang dimaksud dengan syirkah at-tadhâmun adalah sebagai berikut:

$$
\text { والشي الشركة التي يعقدها اثنان أو أكثر بقصد الابحار في جميع أنواع التجارات أو في بعضها، ويكون }
$$

"Bentuk kerjasama antara dua orang atau lebih dengan maksud untuk bebisnis pada semua sektor bisnis atau sebagiannya, yang mana para mitra yang melakukan kerjasama tersebut bertanggung jawab dan saling menjadi jaminan terhadap semua kewajiban badan usaha yang tidak hanya terbatas pada modal semata, akan tetapi bertanggung jawab terhadap keseluruhan harta badan usaha yang didasarkan pada akad syirkah".

${ }^{25}$ Wahbah al-Zuhaili, Fiqh al-Islâmî wa Adillatuh, Beirut, Dâr al-Fikr, 2012, juz. IV, hlm. 665-675. lihat juga, 'Ali al-Khafif, al-Syrkât fî al-Fiqh al-Islâmî: Buhûts Muqâranah, Kairo, Dâr alFikr al-'Arabi, 2009, hlm. 123-127.

${ }^{26}$ Wahbah al-Zuhaili, Loc. Cit., hlm. 668. 
Menurut Wahbah Zuhaili, bahwa dalam syirkah at-tadhâmun terdapat unsur tanggungan dan keterikatan dan hal ini mirip dengan syirkah mufâwadhah yang

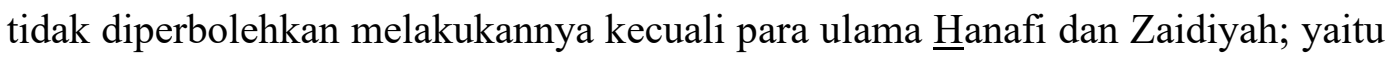
kerjasama dalam bisnis dengan syarat adanya kesamaan jumlah modal yang disertakan, kesamaan jenis kegiatan bisnis yang dilakukan, dan kesamaan agama para mitra; dan setiap mitra bertanggngjawab atas tindakan atau perbuatan hukum yang dilakukan oleh para mitra lainnya yang berkaitan dengan kerjasama tersebut. Akan tetapi, syirkah mufâwadhah merupakan bentuk kerjasama yang sulit dilakukan sehingga jarang sekali teraplikasikan dan akhirnya kebanyakan orang melakukan syrkah inan, karena dalam syirkah inan tidak terdapat adanya kesamaan mengenai jumlah modal, jenis bisnis, dan agama. Oleh karena itu, syrkah inan lebih mudah diaplikasikan. Kaena dalam syirkah inan tidak ada persyaratan mengenai kesamaan modal, jenis bisnis dan agama para mitra yang melakukan kerjasama, juga tidak mengandung akad kafâlah atau dhamânah. Para mitra yang bekerjasama yang satu tidak bertanggungjawab atas perbuatan hukum yang dilakukan oleh mitra lainnya. Profit (keuntungan) dari hasil kerjasama tersebut dibagi di antara para mitra sesuai dengan kesepakatan di awal akad atau dibagikan secara proporsional dan kerugian pun ditanggung berdasarkan jumlah modal secara proporsional. Karena dalam kaidah fikih jelaskan bahwa:

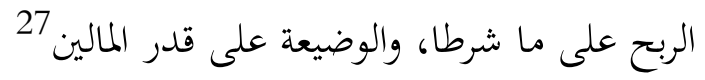

"Keuntungan bisnis dibagai sesuai kesepakatan dan kerugian ditanggung sesuai dengan jumlah modal”.

Menurut Jaih Mubarok dan Hasanuddin, syirkah ini mirip dengan Kitab Undang-Undang Hukum Perdata, Bab kedepalan, Pasal 1618. Dijelaskan bahwa "Persekutuan adalah suatu perjanjian dengan mana dua orang atau lebih mengikatkan diri untuk memasukan sesuatu dalam persekutuan, dengan maksud untuk membagi keuntungan yang terjadi karenanya”. Secara konseptual, syirkah

${ }^{27}$ Kamal al-Din Muhammad Ibn Abd al-Wahib Ibn al-Hamam, Fath al-Qadîr, Beirut, Dâr al-Fikr, t.th, jilid, 6, hlm. 177. 
al-tadhâmun mirip dengan Firma (Fa). ${ }^{28}$ Adapun yang dimaksud dengan Firma adalah jenis persekutuan yang khusus didirikan untuk menjalankan perusahaan dengan nama bersama. Persekutuan jenis ini diatur dalam Pasal 16 sampai dengan Pasal 35 KUHD. ${ }^{29}$

Menurut Neni Sri Imaniyati, Firma merupakan persekutuan perdata khusus, kekhususannya terletak pada 3 (tiga) unsur mutlak sebagai tambahan pada persekutuan perdata, yaitu: ${ }^{30}$

a. Menjalankan perusahaan (Pasal 16 KUHD);

b. Dengan nama bersama

c. irma (Pasal 16 KUHD) dan

d. Pertanggungjawaban sekutu yang bersifat pribadi untuk keseluruhan/Hoofdelij voor het geheel (Pasal 18 KUHD).

\section{Syirkah Taushiyah Basithah}

Menurut Wahbah al-Zuhaili yang dimaksud dengan syirkah taushiyah albasîthah adalah:

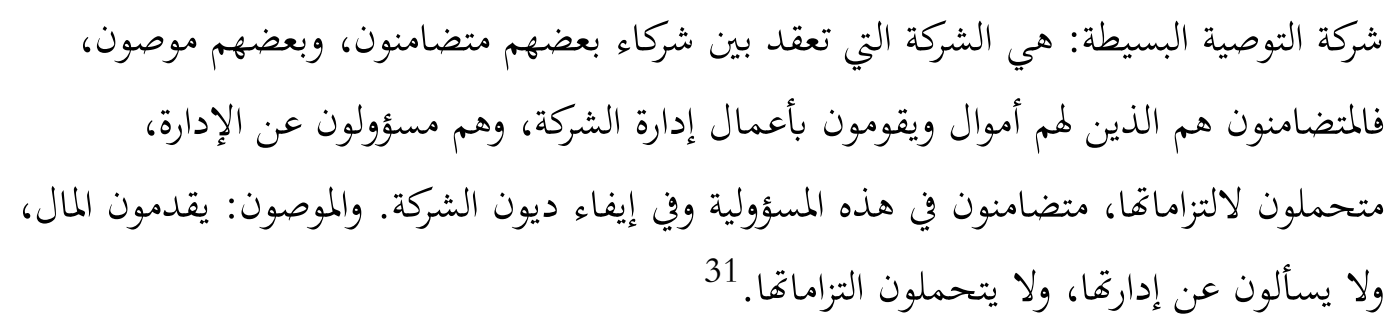

"Bentuk kerjasama antara para mitra, yang mana satu pihak diposisikan sebagai mutadhâmûn dan sebagiannya diposisikan sebagai maushûn. Yang dimaksud dengan mutadhâmûn adalah pihak yang menyertakan modal usaha serta bertanggungjawab atas pengelolaan badan usaha; pihak

${ }^{28}$ Maulana Hasanudin dan Jaih Mubarok, Perkembangan Akad Musyarakah, Jakarta, Kencana Prenada Media, 2012, hlm. 55.

${ }^{29}$ Zaeni Syhadie, Hukum Bisnis: Prinsip Dan Pelaksanaannya Di Indonesia, Jakarta, PT Rajawali Press, , 2014, hlm. 35.

${ }^{30}$ Neni Sri Imaniyati, Hukum Bisnis: Telaah tentang Pelaku Usaha dan Kegiatan Ekonomi, Yogyakarta, Graha Ilmu, 2009, hlm. 174

${ }^{31}$ Wahbah al-Zuhaili, Op. Cit., hlm. 669. 
mutadhâmûn yang merancang, mengorganisir, memanage, menggerakan dan mengontrol badan usaha, sehingga mereka bertindak atas nama dan untuk badan usaha serta bertanggung jawab untuk menunaikan kewajibankewajiban badan usaha; sedangkan maushûn adalah pihak yang menyertakan harta untuk dijadikan modal badan usaha yang tidak bertanggung jawab atas manajemen badan usaha dan juga dibebani kewajiban-kewajiban badan usaha".

Menurut Maulana Hasanudin dan Jaih Mubarok, syirkah taushiyah albasîthah mirip dengan Perseroan Komanditer/Commanditaire Vennootschaap/CV. ${ }^{32}$ Perseroan Komanditer diatur dalam Pasal 19, 20 dan 21 KUHD.

Pasal 19 KUHD menyatakan bahwa:

"Perseorang secara melepas uang yang juga dinamakan perseroan komanditer, didirikan natara satu orang atau beberapa persero yang secara tanggung-menanggung bertanggung jawab untuk seluruhnya pada pihak satu, dan satu orang atau lebih sebagai pelepas uang pada pihak lain. Dengan demikian bisa terjadi suatu perseroan itu pada suatu ketika yang sama merupakan perseroan firma terhadap para persero firma di dalamnya dan merupakan persroan komanditer terhadap pelepas uang”.

Pasal 20 KUHD menjelaskan bahwa;

"Dengan tak mengurangi kekecualian tersebut dalam ayat kedua Pasal 30, nama persero pelepas uang tidak boleh dipakai dalam firma. Persero yang berlakangaan ini tak diperbolehkan melakukan perbuatan-perbuatan atau bekerja dalam perusahaan perseroan, biar kiranya ia dikuasakan untuk itu sekalipun ia tidak usah menanggung kerugian yang lebih dari jumlah uang yang telah atau harus dimasukan olehnya sebagai modal dalam perseroan, pula tak perlu mengembalikan segala keuntungan yang telah dinikmatinya".

Pasal 21 KUHD menyebutkan bahwa:

"Tiap-tiap persero-pelepas uang yang melanggar ketentuan ayat kesatu atau kedua dari pasal yang lalu adalah secara tanggung menanggung bertanggung jawab untuk seluruhnya atas segala utang dan segala perikatan dari perseroan".

Perseroan Komanditer atau Commanditaire Vennootschaap sering disingkat dengan "CV" atau dalam bahasa Inggris disebut dengan "Limited Corporation",

${ }^{32}$ Maulana Hasanudin dan Jaih Mubarok, Op. Cit., hlm. 57. 
merupakan syatu bentuk badan usaha yang didirikan oleh 2 (dua) orang atau lebih, dimana 1 (satu) orang atau lebih dari pendinya adalah persero aktif, yakni yang menjalankan perusahaan dan akan bertanggungjawab secara penuh atas kekayaan pribadinya, sementara 1 (satu) orang lain atau lebih merupakan persero pasif (persero komanditer), dimana dia hanya bertanggungjawab sebatas uang yang disetor saja. ${ }^{33}$

Kemudian Wahbah al-Zuhali menjelaskan mengenai status hukum syirkah taushiyah al-basîthah sebagai berikut:

"Syirkah taushiyah al-basîthah hukumnya adalah boleh (jâiz) karena syirkah ini berakar pada syirkah 'inan dan syirkah mudhârabah'. Pertama, syirkah taushiyah al-basithah dianggap sebagai pengembangan dari syirkah 'inan karena dalam syirkah 'inan masing-masing mitra menyediakan harta untuk dijadikan modal usaha, dan dibolehkan adanya syarat yang menetapkan bahwa modal syirkah dikelola hanya oleh salah satu pihak mitra dan yang bersangkutan wajib bertanggung jawab atas pengelolaan badan usaha. Dibolehkan juga adanya syarat bahwa pihak mitra yang mengelola badan usaha berhak mendapatkan keuntungan yang lebih besar, atau pihak mitra yang mengelola badan usaha berhak mendapatkan imbalan daru basan usaha yang dikelola atas jasa yang dilakukannya. Di samping itu, dibolehkan juga adanya syarat yang menetapkan bahwa hanya pihak mitra (mutadhâmin) yang mengelola badan usaha yang bertanggung jawab untuk bertindak atas nama dan usaha badan usaha, sedangkan pihak mushi tidak boleh bertindak atas nama dan untuk badan usaha dan sekaligus tidak dapat diminta pertanggungjawaban atas kewajiban-kewajiban badan usaha, seperti telah dijelaskan dalam syirkah at-tadhâmun. ${ }^{34}$

Kedua, syirkah taushiyah al-basîthah dianggap sebagai pengembangan dari syirkah mudhârabah karena mitra (mushi) berkedudukan sebagai investor (pemilik modal) yang tidak bertanggung jawab atas pengelolaan usaha yang tidak boleh ikut

${ }^{33}$ Rudyanti Dorote Tobing, Aspek-Aspek Hukum Bisnis: Pengertian, Asas, Teori dan Praktik, Surabaya, LaksBang Justisia, 2015, hlm. 267.

${ }^{34}$ Maulana Hasanudin dan Jaih Mubarok, Loc. Cit., hlm. 57. 
campur dalam pengelolaan badan usaha, dan tidak dibebani kewajiban-kewajiban badan usaha. Adapun pihak mutadhâmin berkedudukan sebagai mudharib; yaitu pihak yang mengelola badan usaha yang didasarkan pada modal yang dimiliki shâhib al-mâl. Apabila terjadi kerugian, pihak mitra mushi (shâhib al-mâl) yang harus bertanggung jawab atas kerugian tersebut, sedangkan mitra mutadhâmin hanya rugi tenaga yang tidak boleh ditambah bebannya dengan kewajiban yang bersifat material (seperti kewajiban membayar hutang). Keuntungan yang diterima oleh mushi (shâhib al-mâl) dan mutadhâmin sesuai dengan nisbah yang disepakati dalam akta perjanjian seperti dalam syirkah mudhârabah. ${ }^{35}$

\section{Syirkah Muhâshah}

Wahbah al-Zuhaili menguraikan mengenai karakteristik dari syirkah muhâshah sebagai berikut:

$$
\begin{aligned}
& \text { شركة المحاصة: هي عقد كباقي العقود، بمقتضاه يلتزم شخصان أو أكثر بأن يساهم كل منهم في }
\end{aligned}
$$

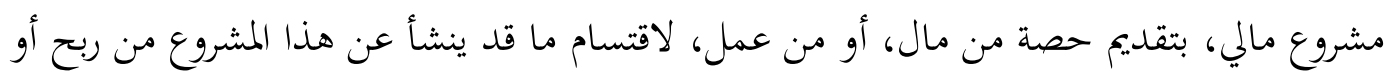

$$
\begin{aligned}
& \text { من خسارة، إلا أفها تمتاز بخفائها عن الجمهور، فليس لها رأس مال شركة، ولا عنوان شركة، فهي } \\
& \text { غير معروفة من الناس، وليس لها وجود ظاهر، وليس لها شخصية معنوية مستقلة كباقي الشركات. }
\end{aligned}
$$

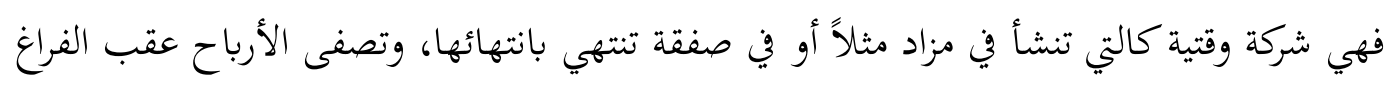

$$
\begin{aligned}
& \text { منها. فالذي يبرز منها شريك واحد يتعامل في الظاهر باسمه، وتبقى الشركة مستترة، ليس لها } \\
& \text { شخصية اعتبارية. } 36
\end{aligned}
$$

"syirkah muhâshah tidak sama halnya seperti dengan akad syirkah lainnya yang mengharuskan dua pihak atau lebih untuk menyertakan modal yang berupa harta dan/atau skill untuk mendapatkan profit; dalam syirkah muhâshah tidak terdapat penyertaan modal berupa harta untuk dijadikan sebagai modal bersama juga tidak pula terdapat karakteristik jenis kontrak khsusus syirkah, oleh karena itu, syirkah muhâshah luput dari perhatian mayoritas ulama serta tidak dikenal oleh masyarakat pada umumnya, tidak ada wujud secara spesifik, dan juga tidak ada badan usaha sebagai subjek hukum seperti kelazimannya yang terjadi pada akad syirkah pada umumnya. syirkah muhâshah disebut pula dengan istilah syirkah temporal seperti lelang atau jual beli yang menggunakan jasa pihak ketiga guna memperoleh laba bersih secara cepat dan seketika setelah penjualan atau

${ }^{35}$ Ibid., hlm. 58.

${ }^{36}$ Wahbah al-Zuhaili, Op. Cit., hlm. 670. 
lelang berlangsung. Hal yang konkret adalah bahwa salah satu mitra mewakili mitra lainnya untuk bertindak secara hukum atas nama mitra lainnya, pada saat itulah syirkah berlangsung, dan tidak ada badan usaha syirkah".

Lebih lanjut Wahbah al-Zuhaili berpendapat bahwa syirkah muhâshah hukumnya adalah dibolehkan oleh para ulama karena dianggap sebagai pengembangan dari akad syirkah inan yang di dalamnya tidak dapat syarat mengenai kesamaan dalam modal dan keterampilan, dan tidak terdapat pula unsur jaminan dan tanggungan, akan tetapi termasuk bagin dari akad mu'âwadat (akadakad yang bertujuan untuk mencari profit), serta keuntungan dibagi sesuai kesepakatan sementara kerugian dibebankan berdasarkan jumlah modal secara proporsional.

Dari segi sifatnya, syirkah muhâshah juga dianggap sebagai pengembangan dari syirkah inan apabila masing-masing bagian modal dan keterampilan yang dijadikan syirkah sebagai milik bersama. syirkah muhâshhah juga dianggap sebagai pengembangan dari syirkah inan dan mudhârabah apabila masing-masing mitra menjaga modalnya masing-masing tetapi dalam praktiknya modal tersebut diserahkan kepada salah satu mitra untuk dijadikan modal usaha demi terwujudnya kemaslahatan bersama; adapun mengenai keuntungan dibagi sesuai dengan kesepakatan, sementara kerugian dibagi secara proporsional. Penyerahan harta guana dijadikan sebagai modal usaha dari mitra yang satu terhadap mitra yang lain (mudharib) dianggap sama dengan akad syirkah mudhârabah.

\section{Syirkah Musâhamah}

Syirkah musâhamah adalah penyertaan modal usaha yang dihitung dengan jumlah lembar saham (bukan dalam nominal) yang diperdagangkan di pasar modal sehingga pemiliknya dapat berganti-ganti dengan mudah dan cepat. Dengan penjelasan ini, al-Mishri sebagaimana dikutip oleh M. Hasanuddin dan Jaih Mubarok menegaskan juga bahwa pertangggungjawaban pemagang saham sesuai 
dengan jumlah saham yang dimilikil keyntungan dan kerugian yang diterima oleh oemegang saham sebanding dengan jumlah saham yang dimiliki. ${ }^{37}$

Ulama berbeda pendapat mengenai hukum syikah musâhamah. Pertama, ada ulama yang berpendapat bahwa syirkah musâhamah tidak dibenarkan, karena terjadi pengalihan dari individu syarik ke dalam jumlah kepemilikan saham dalam menentukan arah perusahaan termasuk menentukan pihak pengelola/direksi dan/atau istilah lainnya yang berlaku di lembaga-lembaga bisnis. Jumlah syarik sebagai pemilik saham tidak menentukan arah perushaaan yang berbasis syirkah musâhamah; tetapi yang menentukan adalah pemegang saham mayoritas. Di samping itu, ulama yang tidak membolehkan dilakukannya akad syirkah musâhamah berpendapat bahwa syirkah mushamah mengenyampingkan aspek ridha (rela); padahal aspek ridha adalah aspek penting dalam melakukan perkongsian.

Kedua, ada juga ulama yang berpendapat bahwa syirkah musâhamah hukumnya adalah boleh (jâiz) dilakukan selama memenuhi persyaratan kegiatan usaha yang dilakukannya tidak mencangkup: 1) objek yang haram seperti khamar dan babi; dan 2) cara usaha yang diharamkan seperti usaha yang ribawi dan judi. Alasannya adalah kaidah fikih yang menyatakan bahwa: "Pada dasarnya setiap transaksi muamalah hukumnya adalah boleh" dan kaidah lain menyatakan bahwa: "orang Islam itu terikat dengan syarat-syarat akad yang telah mereka sepakati”.

Ulama yang memperbolehkan syirkah musâhamah menentukan bahwa perpindahan kepemilikan saham harus tunduk pada dhawâbith (kriteria) sebagai berikut: ${ }^{38}$ (1) Apabila harta yang disyirkah-kan berupa modal yang dinilai dengan uang secara tunai; maka perpindahan kepemilikan saham dilakukan dengan akad sharf (pertukaran uang). Perpindahan kepemilikan saham tersebut boleh dilakukan secara tunai (tidak boleh dilakukan dengan cara tangguh) dan keuntungannya boleh diterima; (2) Apabila harta yang disyirkahkan berupa utangl maka hukum yang berlaku adalah hkum utang; yaitu utang tidak boleh dipindahtangankan dengan cara

${ }^{37}$ Ibid., hlm. 170.

${ }^{38}$ Ibid., hlm. 71-72. 
dijual; karena menjual piutang dilarang oleh syariah; (3) Apabila modal yang disyrkahkan berupa barang dagangan atau manfaat, maka tidak ada halangan untuk memindahtangankan dengan cara dijual, dan keuntungannya boleh diterima secara tunai (tidak boleh dengan cara tangguh); (4) Apabila modal yang disyirkahkan berupa barang dagangan, manfaat, uang, dan utang yang disatukanm maka yang dijadikan dasar hukum adalah hukum barang dagangan dan manfaat; yaitu boleh dipindahtangankan dengan cara dijual, dan keuntungannya boleh diterima secara tunai (tidak boleh dengan cara tangguh).

\section{Syirkah Taushiyah Bi al-Asham}

Syirkah taushiyah bi al-asham ia adalah gabungan dua unsur, yakni mutadhâmîn dan musâhimiîn. Musâhimîn seperti mitra mushi dalam syirkah altaushiyah al-basithah. Mutadhâmîn adalah pihak yang menyertakan modal usaha (yang dikonversi ke dalam bentuk saham) serta bertanggung jawab atas pengelolaan badan usaha; pihak mutadhâmîn lah yang merencanakan, mengorganisasikan, mengerakan, dan mengontrol badan usaha, sehingga mereka bertindak atas nama dan untuk badan usaha serta bertanggung jawab untuk menunaikan kewajibankewajiban badan usaha; sedangkan musâhim adalah pihak yang menyertakan harta untuk dijadikan modal (dalam bentuk saham) badan usaha yang tidak bertanggung jawab atas manajemen badan usaha dan juga tidak dibebani kewajiban-kewajiban badan usaha, kecuali laba rugi badan usaha pada akhir tahun buku yang menghasilkan deviden secara proporsional. ${ }^{39}$

Wahbah al-Zuhaili menjelaskan mengenai hukum syirkah taushiah bi alasham sebagai berikut:

$$
\text { وتلكي شركة جائزة شرعاً؛ لأكا نوع من شركات العنان التي يشترط فيها التضامن بين بعض الشركاء، }
$$

${ }^{39}$ Ibid., hlm. 74. 
مساهمين كما بان في شركة المساهة؛ لأن تقديم الحصة بالأسهم جائز شرعاً، خصوصاً إذا انحصر

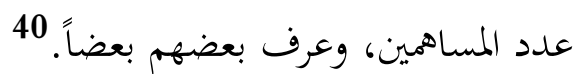

"Syirkah tauhiah bi al-asham hukumnya adalah boleh (jâiz), karena dianggap sebagai pengembangan dari syirkah inan yang di dalamnya terkandung akad dhamânah dan kafâlah. Mutadhâmin memiliki kebebasan melakukan bisnis apa saja demi menjalankan badan usaha berdasarkan izin para mitra yang lainnya; di samping itu; mutadhâmin dalam menjalankan usaha tunduk patuh pada hukum syirkah mudhârabah; dan dalam syirkah taushiah bi al-asham dibolehkan adanya saham preferen, yaitu saham yang pemiliknya berhak didahulukan untuk mendapatkan dviden atau bagian kekayaan dalam hal perusahana dilikuidasi, tetapi pemegang saham preferen tidak memiliki hak suara dalam Rapat Umum Pegegang Saham (RUPS)".

\section{Syirkah Mas'uliah}

Menurut Wahbah al-Zuhaili yang dimaksud dengan syirkah mas'uliah mahdûdah adalah sebagai berikut:

$$
\begin{aligned}
& \text { الشركة ذات المسؤولية المحدودة: هي شركة بحارية كباقي شركات الأموال، لا اعتبار فيها } \\
& \text { لشخصية الشركاء، واشترط القانون فيها ألا يزيد عدد الشركاء عن خمسين شريكاً، لا يكون كل } \\
& \text { منهم مسؤولاً إلا بقدر حصته. فهي بتمع بين خصائص شركات الأموال وشركات الأشخاص. }
\end{aligned}
$$

"Bentuk kerjasama bisnis yang serupa dengan syirkah amlwâl. Dalam syirkah mas 'uliah mahdûdah tidak ada badan usaha perkongsian; dan dalam peraturan perundang-undangan ditetapkan bahwa jumlah mitra yang berkongsi tidak lebih dari 50 (lima puluh) mitra; setiap mitra bertanggung jawab sesuai dengan jumlah saham yang dimilikinya. Oleh karena itu, syirkah mas'uliah mahdûdah merupakan gabungan antara syirkah amwâl dan syirkah abdân".

Lebih lanjut Wahbah Zuhalili menjelaskan bahwa:

$$
\begin{aligned}
& \text { ففيها من شركات الأموال أن مسؤولية الشريك محدودة بمقدار حصته، وأن حصته تنتقل إلى ورثثه، } \\
& \text { وإدارتا كما في شركات المساهمة، يجوز أن يعين لها مدير من المساهمين أو من غيرهم بمرتب محدد، }
\end{aligned}
$$

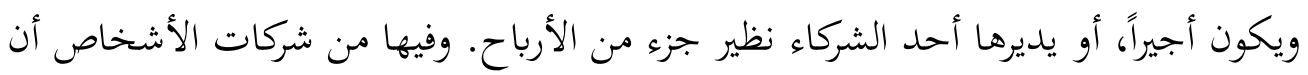

${ }^{40}$ Wahbah al-Zuhaili, Op. Cit., hlm. 672. 


$$
\begin{aligned}
& \text { الشريك يكون صاحب حصة في الشركة وليس مساهماً، ولا تكون حصص الشركاء قابلة للتداول } \\
& \text { كالأسهم التجارية. وأهم ما يميزها أها تتم بالاشتراك الشخصي لا بالاكتتاب العام. } 41
\end{aligned}
$$

"Syirkah mas'uliah mahdûdah merupakan pengembangan dari syirkah amwâl karena pertanggungjawaban mitra terbatas, yaitu terbatas pada prosi saham yang dimilikinya. Apabila kepemilikan saham beralih kepada ahli warisnya, sementara pengelolaan syirkah mirip dengan syirkah musâhamah, maka pihak pemegang saham diperbolehkan menunjuk manajer perusahaan baik yang berasal dari kalangan pemegang saham ataupun bukan. Dan manajer berhak mendapatkan fee (upah) atau pendapatan yang ditentukan secara dinamis yang berupa prosentasi dari profit perusahaan. Apabila manajer berasal dari pemegang saham, maka syirkah tersebut termasuk pengembangan dari syirkah abdân karena manajer berhak mendapatkan penghasilan sesuai kesepakatan, bukan atas dasar saham. Modal yang dinilai dengan saham tidak dapat dipindahtangankan seperti layaknya saham di pasar modal".

Lebih lenjut Wahbah al-Zuhali menjelaskan mengenai status hukum dari syirkah mas'uliah mahdûdah sebagai berikut:

$$
\text { وكل ذلك جائز شرعاً، وتعتبر هذه الشركة من شركات العنان، وقد يكون فيها بعض ألمضاربة كما في تحديد مسؤولية الشريك بمقدارحصته، كما أن رب المال في المضاربة لا }
$$

"Hukum syirkah mas'uliah mahdûdah adalah boleh dan merupakan pengembangan dari syirkah inan. Adapun dari aspek tanggungjawab, syirkah mas'uliah mahdûdah dianggap sebagai pengembangan dari sirkah mudhârabah karena tanggung jawab mitra terbatas pada porsi bagiannya, seperti tanggung jawab investor (shâhib al-mâl) dalam akad mudhârabah terbatas pada jumlah moal yang diinvestasikannya".

Wahbah al-Zuhaili mengambil kesimpulan sebagai berikut:

$$
\begin{aligned}
& \text { والخلاصة: إن هذه الشركات التي أقرها القانون المدني ليست غريبة عن قواعد الفقه الإسلامي، وإنما } \\
& \text { هي منسجمة مع أنظمة الشركات التي عرفها فقهاؤنا، ولكنها متطورة بحسب حاجة العصر وعرفه، }
\end{aligned}
$$

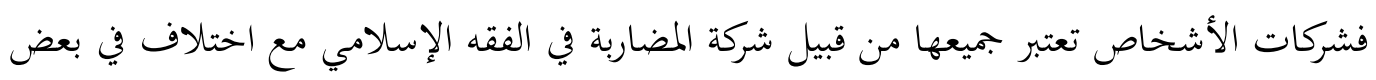

$$
\begin{aligned}
& \text { الأحكام بين الشريعة والقانون حسبما تقتضيه مصلحة الناس وطبيعة التطور. وشركات الأموال تعتبر }
\end{aligned}
$$

${ }^{41}$ Ibid.

${ }^{42}$ Ibid., hlm. 673. 


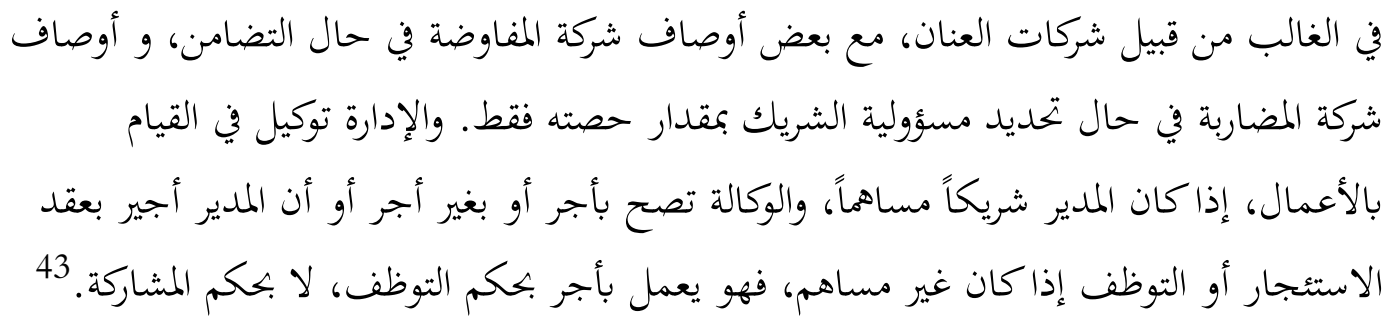

"Sejumlah syirkah yang ditetapkan dalam undang-undang Perdata tidaklah tergolong asing, karena syirkah yang dikenal telah tertuang dalam kaidahkaidah syirkah yang dikenalkan oleh para pakar fikih. Konsep-konsep tersebut berkembang sesuai dengan kebutuhan manusia modern. Syirkah alAsykhâs (badan usaha) merupakan pengembangan dari konsep syirkah mudhârabah yang masing-masing pihak memiliki tanggung jawab yang terbatas, dan pihak manajeman adalah wakil dari para pemegang saham, dalam hal itu merupakan salah satu pemegang saham, dan pendelegasiannya boleh dilakukan dengan adanya fee atau tanpa adanya fee, sedangkan manajemen yang bukan berasal dari pemegang saham berhak mendapat imbalan yang berupa fee".

\section{SIMPULAN}

1. Badan hukum dalam perpsketif hukum ekonomi syariah kedudukannya diakui sebagai subjek hukum, hal ini berdasarkan analogi dari keberadaan manusia sebagai subjek hukum selama tidak bertentang dengan prinsip syariah. Dalam istilah fikih muamalah badan hukum biasa disebut dengan syakhsyiyyah i'tibariyah. Terlebih dalam konteks hukum Indonesia, kedudukan badan hukum sebagai subjek hukum diatur dalam Kompilasi Hukum Ekonomi Syariah Bab Subjek Hukum.

2. Badan hukum dalam konteks hukum ekonomi syariah, terimplementasikan dalam akad-akad perkongsian/musyârakah lebih khusus pada akad-akad musyârakah mu'âshirah (perkongsian kontemporer) seperti Syirkah AtTadhâmun, Syirkah Taushiyah Basithah, Syirkah Muhâshah, Syirkah Musâhamah, Syirkah Taushiyah Bi al-Asham, Syirkah Mas'uliah.

${ }^{43}$ Ibid. 


\section{DAFTAR PUSTAKA}

\section{A. Buku}

Ali al-Khafif, al-Syrkât fî al-Fiqh al-Islâmî: Buhûts Muqâranah, Kairo, Dâr al-Fikr al-'Arabi, 2009.

Agustianto, Reaktualisasi dan Kontekstualisasi Fikih Muamalah Ke-Indonesiaan: Upaya Inovasi Produk Perbankan dan Keuangan Syariah, Iqtishad Publishing, Ciputat, 2014.

Atang Abd Hakim, Fiqih Perbankan Syariah: Transformasi Fiqih Muamalah Ke dalam Peraturan Perundang-Undangan, Bandung, Refika Aditama, 2011.

Burhanuddin S, Hukum Bisnis Syariah, Yogyakarta, UII Press, 2011.

Chaidir Ali, Badan Hukum, Bandung, Alumni, 1991.

Darsono, dkk, Perbankan Syarah Di Indonesia: Kelembagaan Dan Kebijakan Serta Tantangan Ke Depan, PT RajaGrafindo Persada, Jakarta, 2017.

Fathurrahman Djamil, Penerapan Hukum Perjanjian dalam Transaksi di Lembaga Keuangan Syariah, Jakarta, Sinar Grafika, 2012.

Hasbi Hasan, Pemikiran Dan Perkembangan Hukum Ekonomi Syariah Di Dunia Islam Kontemporer, Gramata Publishing, Depok, 2011.

Hendi Suhendi, Fiqh Muamalah, Jakarta, PT RajaGrafindo Persada, 2005.

Imron Rosyadi, Akad Nominaat Syariah: Implementasi dan Penyelesaian Sengketa, Jakarta, Kencana Prenada Media Group, 2019.

Izzudin Muhammad Khujah, Nadzariyat al-'Aqd fî̀ al-Fiqh al-Islâmî, Jeddah, Dallah al-Barakah, 1993.

Kamal al-Din Muhammad Ibn Abd al-Wahib Ibn al-Hamam, Fath al-Qadîr, Beirut, Dâr al-Fikr, t.th.

Khalid Ibn Abdullah al-Aziz Ibn Ibrahim al-Juraid, al-Syakhsiyyah al-I'tibâriyah, t.t, t.p, t.th.

Maulana Hasanudin dan Jaih Mubarok, Perkembangan Akad Musyarakah, Jakarta, Kencana Prenada Media, 2012. 
Musthafa Ahmad Zarqa, al-Madkhal al-Fiqh al-'Âm: Fiqh al-Islâm fì Tsaubih alJadîd, Beirût, Dâr al-Fikr, 1986.

Neni Sri Imaniyati, Hukum Bisnis: Telaah tentang Pelaku Usaha dan Kegiatan Ekonomi, Yogyakarta, Graha Ilmu, 2009.

Oni Sahroni dan M. Hasanuddin, Fikih Muamalah: Dinamika Teori Akad dan Implementasinya dalam Ekonomi Syariah, Jakarta, RajaGrafindo Persada, 2016.

Rudyanti Dorote Tobing, Aspek-Aspek Hukum Bisnis: Pengertian, Asas, Teori dan Praktik, Surabaya, LaksBang Justisia, 2015.

Syamsul Anwar, Hukum Perjanjian Syariah: Studi tentang Teori Akad dalam Fikih Muamalat, Jakarta, RajaGrafndo Persada, 2007.

Teungku Muhammad Hasbi Ash-Shiddieqy, Pengantar Fiqh Muamalah, Semarang, PT Pustaka Rizki Putra, 2001.

Wahbah al-Zuhaili, Fiqh al-Islâmî wa Adillatuh, Beirut, Dâr al-Fikr, 2012.

Zaeni Syhadie, Hukum Bisnis: Prinsip Dan Pelaksanaannya Di Indonesia, Jakarta, PT Rajawali Press, , 2014.

\section{B. Peraturan Perundang-Undangan}

Kitab Undang-Undang Hukum Dagang.

Undang-Undang Nomor 21 Tahun 2008 tentang Perbankan Syariah.

Peraturan Mahkamah Agung RI Nomor 2 Tahun 2008 tentang Kompilasi Hukum Ekonomi Syariah. 